\title{
Daidalotarsonemus and Excelsotarsonemus species (Acari: Tarsonemidae) found in shaded cacao plantations in Brazil, with a description of a new species
}

André Silva Guimarães Sousa, José Marcos Rezende, Antonio Carlos Lofego, Ronald Ochoa \& Anibal Ramadan Oliveira

To cite this article: André Silva Guimarães Sousa, José Marcos Rezende, Antonio Carlos Lofego, Ronald Ochoa \& Anibal Ramadan Oliveira (2018) Daidalotarsonemus and Excelsotarsonemus species (Acari: Tarsonemidae) found in shaded cacao plantations in Brazil, with a description of a new species, International Journal of Acarology, 44:2-3, 68-79, DOI: 10.1080/01647954.2018.1471096

To link to this article: https://doi.org/10.1080/01647954.2018.1471096

曲 Published online: 24 May 2018.

Submit your article to this journal $[\pi$

Llll Article views: 80

View Crossmark data \lceil 


\title{
Daidalotarsonemus and Excelsotarsonemus species (Acari: Tarsonemidae) found in shaded cacao plantations in Brazil, with a description of a new species
}

\author{
André Silva Guimarães Sousa ${ }^{a}$, José Marcos Rezende ${ }^{b}$, Antonio Carlos Lofego $\mathbb{B}^{b}$, Ronald Ochoa \\ and Anibal Ramadan Oliveira ${ }^{a}$ \\ aPrograma de Pós-graduação em Produção Vegetal (PPGPV), Universidade Estadual de Santa Cruz (UESC), Ilhéus, BA, Brazil; bepartamento de \\ Zoologia e Botânica, Universidade Estadual de São Paulo (UNESP), Instituto de Biociência, Letras e Ciências Exatas (IBILCE), SP, Brazil; 'Systematic \\ Entomology Laboratory, United States Department of Agriculture, Agricultural Research Service, Beltsville, MD, USA
}

\begin{abstract}
Mites of the family Tarsonemidae (Acari: Prostigmata) exhibit a great diversity of feeding habits including fungivorous, algivorous, plant feeders, and predatory of other mites, as parasitoids and parasites are kinds of symbionts of other insects. They also have a considerable diversity of morphological structures, including the shape and structure of the mouthparts and specialized tactile organs, particularly the setae on the body and legs. The Atlantic Forest remnant is considered to be a very diverse tropical biota. Samples were collected on Theobroma cacao and Artocarpus heterophyllus trees in cabruca agroforest systems located in Ilhéus, Bahia State, Brazil. A new species, Excelsotarsonemus cabrucae Sousa, Lofego \& Ochoa, sp. $\mathrm{n}$. is described and illustrated. Six Daidalotarsonemus and three Excelsotarsonemus species were identified in the same area. A key to the species of Daidalotarsonemus of Brazil and a key to the species of Excelsotarsonemus of the world are presented. The findings emphasize the importance of conducting mite surveys in rainforests to better understand the mite diversity which inhabits this biome.

http://www.zoobank.org/urn:Isid:zoobank.org:act:15D43DCE-E281-456F-B218-6F0947B6EA04
\end{abstract}

\section{ARTICLE HISTORY}

Received 10 January 2018 Accepted 26 April 2018

Published online 24 May

2018

\section{KEYWORDS}

Atlantic Forest; cabruca: taxonomy; systematic; Tarsonemoidea

\section{Introduction}

The Tarsonemidae (Acari: Prostigmata) currently consists of 43 genera (Lin and Zhang 2002; Magowski et al. 2005; Lofego and Feres 2006; Lofego et al. 2015, 2016; Khaustov and Abramov 2017). They exhibit a great diversity of feeding habits including fungivorous, algivorous, plant feeders, and predatory of other mites, as parasitoids and parasites are kinds of symbionts of other insects (Lindquist 1986). They also have a considerable diversity of morphological structures, including the shape and structure of the mouthparts and specialized tactile organs, particularly the setae on the body and legs (Lindquist 1986). The genus Daidalotarsonemus De Leon consists of 37 described species recorded from all of the continents except Antarctica (Lindquist 1986; Lin and Zhang 2002); of these, 8 have been recorded from Brazil (Lin and Zhang 2002; Lofego et al. 2005; Sousa et al. 2014; Rezende et al. 2015a, 2015b, 2015c). The genus Excelsotarsonemus Ochoa \& Naskrecki consists of five species only reported from Central and South America (Ochoa et al. 1995; Ochoa and OConnor 1998; Rezende et al. 2015a). Both genera are considered to be fungivorous and algivorous, two food sources commonly found on plants located in humid areas (Ochoa et al. 1995; Ochoa and OConnor 1998; Rezende et al. 2015a).

The southern coastal region of the Bahia state, in Brazil, contains a significant part of the remaining Atlantic Forest and one of the most diverse tropical biotas of the world (Mittermeier et al. 2004; Faria et al. 2006, 2007). Local farmers cultivate the cacao tree, Theobroma cacao L. (Malvaceae), under the rainforest canopy, in shaded cacao plantations called cabrucas (Johns 1999; Schroth et al. 2011; Sambuichi et al. 2012). This agroforest is characterized by high levels of humidity and temperature, favouring the presence of a great diversity of microorganisms and microarthropods (Joly et al. 2014). Although the species diversity of Tarsonemidae in the cabruca is believed to be very great, only three species, Daidalotarsonemus oliveirai, Excelsotarsonemus caravelis, and E. tupi, have been recorded from this habitat (Rezende et al. 2015a). The present paper presents new records of Daidalotarsonemus and Excelsotarsonemus species and describes a new species of Excelsotarsonemus from a cabruca agroforest in Brazil.

\section{Materials and methods}

Samples of branches, leaves, buds, and stem bark of cacao trees and leaves of jackfruit trees (Artocarpus heterophyllus Lam: Moraceae), which form the dense canopy of the cabruca, were collected from May to December 2016 on the campus of the Universidade Estadual de Santa Cruz (UESC) $\left(14^{\circ} 47^{\prime} 47^{\prime \prime} \mathrm{S}\right.$ and $39^{\circ}$ $\left.10^{\prime} 15^{\prime \prime} \mathrm{W}\right)$, llhéus, Bahia. The climate of the region is classified as "Af" (tropical rainforest climate) of Köppen, due to its high annual temperature $\left( \pm 24^{\circ} \mathrm{C}\right)$ and the high rainfall index ( $\pm 2200 \mathrm{~mm}$ annually) (Canty et al. 2008).

Tarsonemids were extracted from the samples, examined under a Leica EZ4 stereomicroscope, and stored in $70 \%$ ethyl alcohol. The mites were analysed using three different microscopy techniques: phase contrast (PC), differential interferential contrast (DIC), and scanning electron microscopy (SEM). For PC and DIC, some specimens were mounted on slides using Hoyer's medium and analysed under a Zeiss Axioscope ${ }^{\mathrm{TM}}$. For the SEM, specimens were dehydrated in an ascending ethanol series (70$100 \%$ ) followed by a similar ascending series utilizing pentane (25-100\%), dripped onto stubs and left to dry. The stub preparations were coated with gold using an SCD 050 sputter coater. SEM analyses were performed at the Centro de Microscopia Eletrônica (CME) of UESC using a FEI Quanta 250 microscope with Microscope Control software for image capturing.

The terminology used in this paper follows Lindquist (1986), except for the gnathosomal setae dgs and vgs (Suski 1967; Magowski et al. 1998). For each structure, measurements are given 
in micrometres $(\mu \mathrm{m})$, with the holotype value in bold, followed by the average measurement and the respective range in parentheses based on all specimens, including the holotype. The legs were measured from the base of the trochanter to the apex of the tarsus, excluding the pretarsus. The following abbreviations are used for the acarological collections where the type specimens are deposited: Departamento de Zoologia e Botânica, Universidade Estadual Paulista (UNESP), São José do Rio Preto, São Paulo, Brazil [ACDZSJRP]; Universidade Estadual de Santa Cruz (UESC), Ilhéus, Bahia, Brazil [AC-UESC]; Escola Superior de Agricultura "Luiz de Queiroz" (ESALQ), Universidade de São Paulo, Piracicaba, São Paulo, Brazil [AC-ESALQ]; and United States National Museum of Natural History (USNM), Smithsonian Institution, hosted in Beltsville, Maryland, USA [AC-USNM]. Vouchers of the other Daidalotarsonemus and Excelsotarsonemus species reported herein are deposited at ACDZSJRP and AC-UESC.

\section{Results}

Data for the six Daidalotarsonemus and three Excelsotarsonemus species identified in the study are presented below.

Daidalotarsonemus annonae Sousa, Lofego and Gondim Jr 2014: 430.

\section{Material examined}

A. heterophyllus leaves: 16-II-2016 (3); T. cacao branches: 15-III2016 (1); T. cacao leaves 03-V-2016 (1), 14-IX-2016 (1), 07-XII2016 (1).

Daidalotarsonemus esalqi Rezende, Lofego \& Ochoa 2015: 436

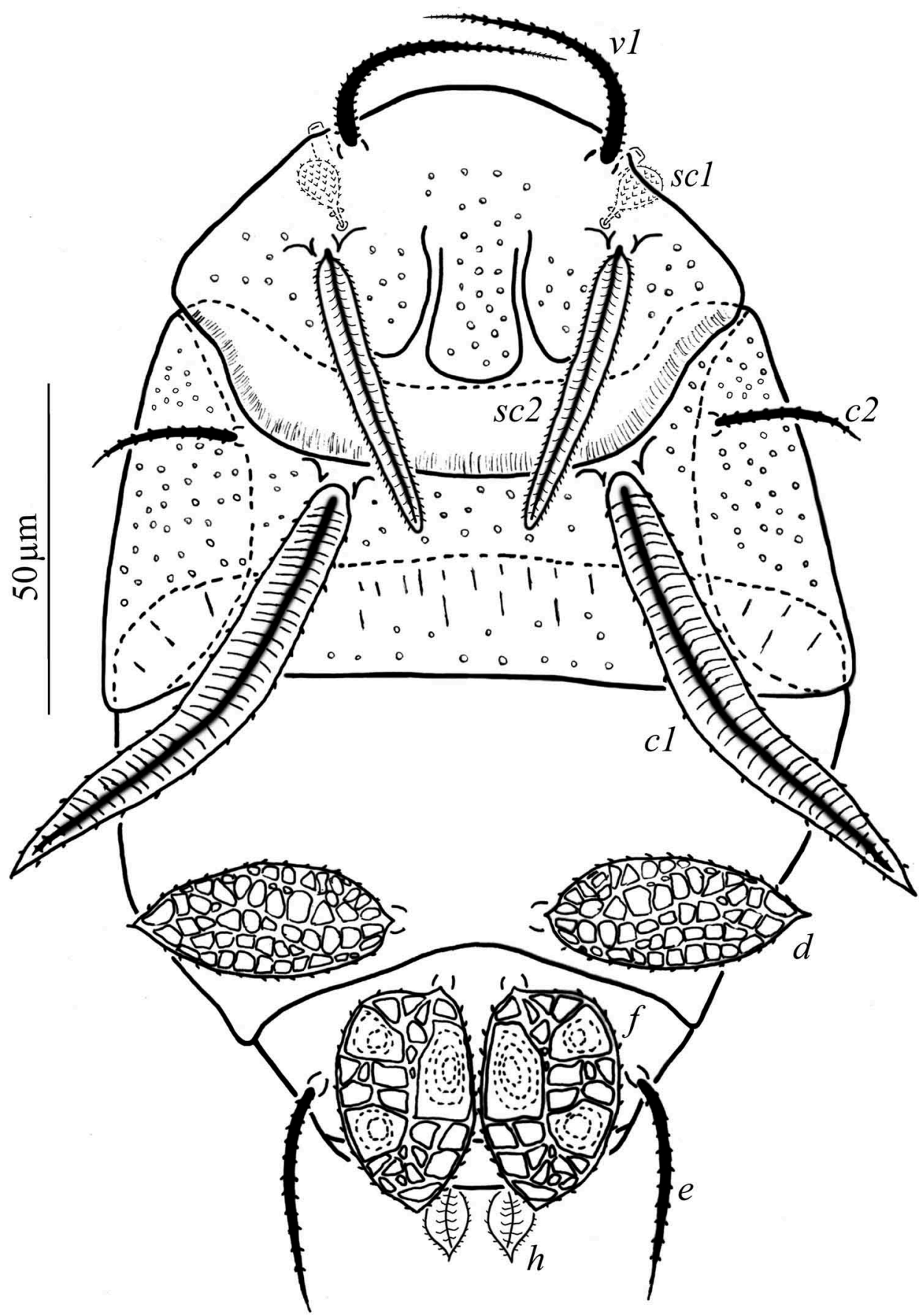

Figure 1. Excelsotarsonemus cabrucae sp. n. (female). Dorsal surface. 

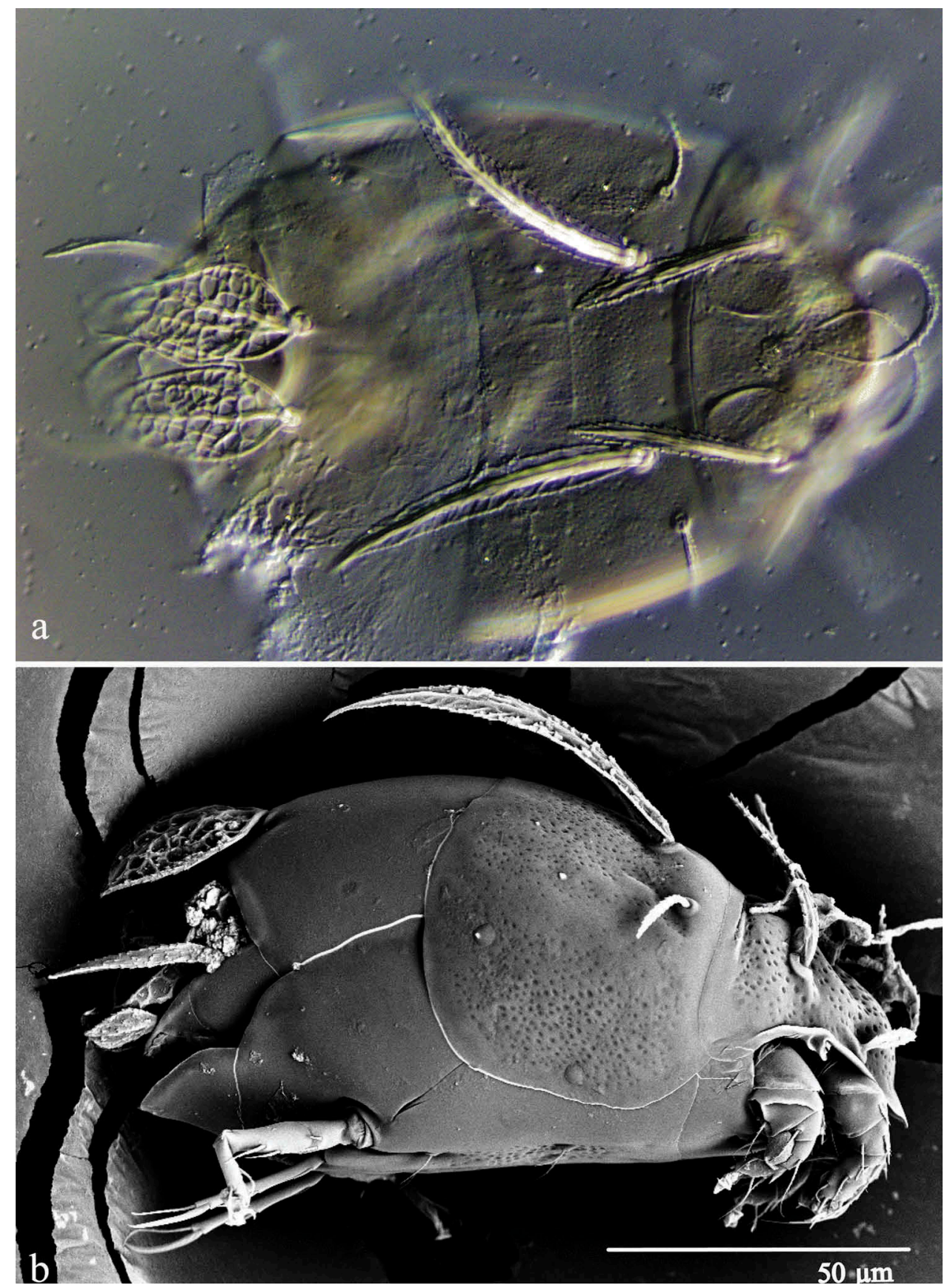

Figure 2. Excelsotarsonemus cabrucae sp. n. (female). Dorsal and lateral micrographs: (a) differential interference contrast and (b) scanning electron microscopy.

\section{Material examined}

A. heterophyllus leaves: 16-II-2016 (1); T. cacao bark: 03-V-2016 (2); T. cacao leaves: 03-V-2016 (4); T. cacao branches: 07-VI-2016 (2); T. cacao leaves: 14-IX-2016 (2).

Daidalotarsonemus lini Ochoa, Rezende \& Lofego 2015: 25

\section{Material examined}

T. cacao leaves: 14-IX-2016 (1), 09-XI-2016 (3), 07-XII-2016 (1).

\section{Remarks}

This represents the first record of this species in the South America.

Daidalotarsonemus maryae Ochoa, Rezende \& Lofego 2015: 33.

\section{Material examined}

T. cacao branches: 15-III-2016 (1), 14-VIII-2016 (2), 09-XI-2016 (3).

Remarks

This represents the first record of this species in the South America.

Daidalotarsonemus oliveirai Rezende, Lofego \& Ochoa 2015: 3.

\section{Material examined}

A. heterophyllus leaves: 16-II-2016 (4), 19-X-2016 (7); T. cacao leaves: 16-II-2016 (10), 15-III-2016 (10), 03-V-2016 (9), 14-VIII-2016 (1), 14IX-2016 (19), 19-X-2016 (48), 09-XI-2016 (13), 07-XII-2016 (85).

Daidalotarsonemus savanicus Ochoa, Rezende \& Lofego 2015: 441.

\section{Material examined}

T. cacao leaves: 18-I-2016 (1), 14-IX-2016 (3), 07-XII-2016 (1). 


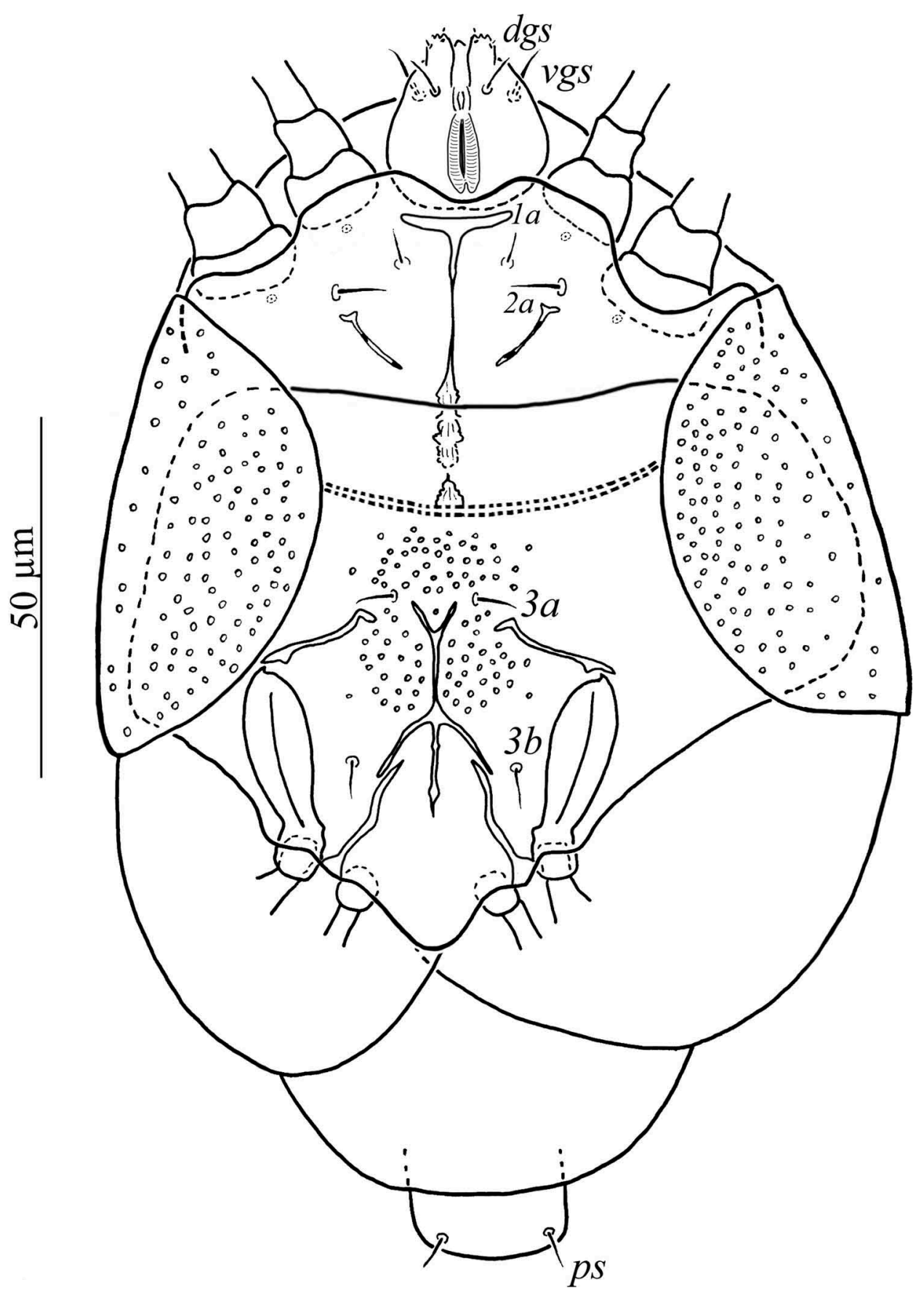

Figure 3. Excelsotarsonemus cabrucae sp. n. (female). Ventral surface.

Excelsotarsonemus caravelis Rezende, Lofego \& Ochoa 2015: 18.

\section{Material examined}

A. heterophyllus leaves: 16-II-2016 (1), 12-IV-2016 (1), 14-VIII-2016 (7), 19-X-2016 (22); T. cacao leaves: 03-V-2016 (13), 14-VIII-2016 (127), 19-X-2016 (132), 09-XI-2016 (1), 07-XII-2016 (15);

Excelsotarsonemus tupi Rezende, Lofego \& Ochoa 2015: 25.

\section{Material examined}

T. cacao leaves: 26-V-2016 (2), 07-VI-2016 (1), 19-X-2016 (1).

Excelsotarsonemus cabrucae Sousa, Lofego \& Ochoa, sp. $\mathbf{n}$. (Figures 1-7)

\section{Material examined}

A. heterophyllus leaves: 14-VIII-2016 (4); T. cacao leaves: 18-I-2016 (1), 16-II-2016 (1), 15-III-2016 (1), 07-XII-2016 (1).

\section{Diagnosis}

Excelsotarsonemus cabrucae sp. $\mathrm{n}$. has apodeme 4 extending diagonally from the middle portion of the poststernal apodeme nearly to the base of femorogenu III and base of trochanter IV, whereas in E. tupi and E. kaliszewskii, apodeme 4 extends diagonally from the middle of the poststernal apodeme to base of seta $3 b$.

\section{Differential diagnose}

Females of the new species Excelsotarsonemus cabrucae are similar to those of E. kaliszewskii Ochoa \& Naskręcki (Ochoa et al. 1995) and E. tupi Rezende, Lofego \& Ochoa (Rezende et al. 2015a), based on the similar shape of setae $c 1$ and $d$. However, the shape of setae sc2 in Excelsotarsonemus cabrucae sp. n. is lanceolate, 

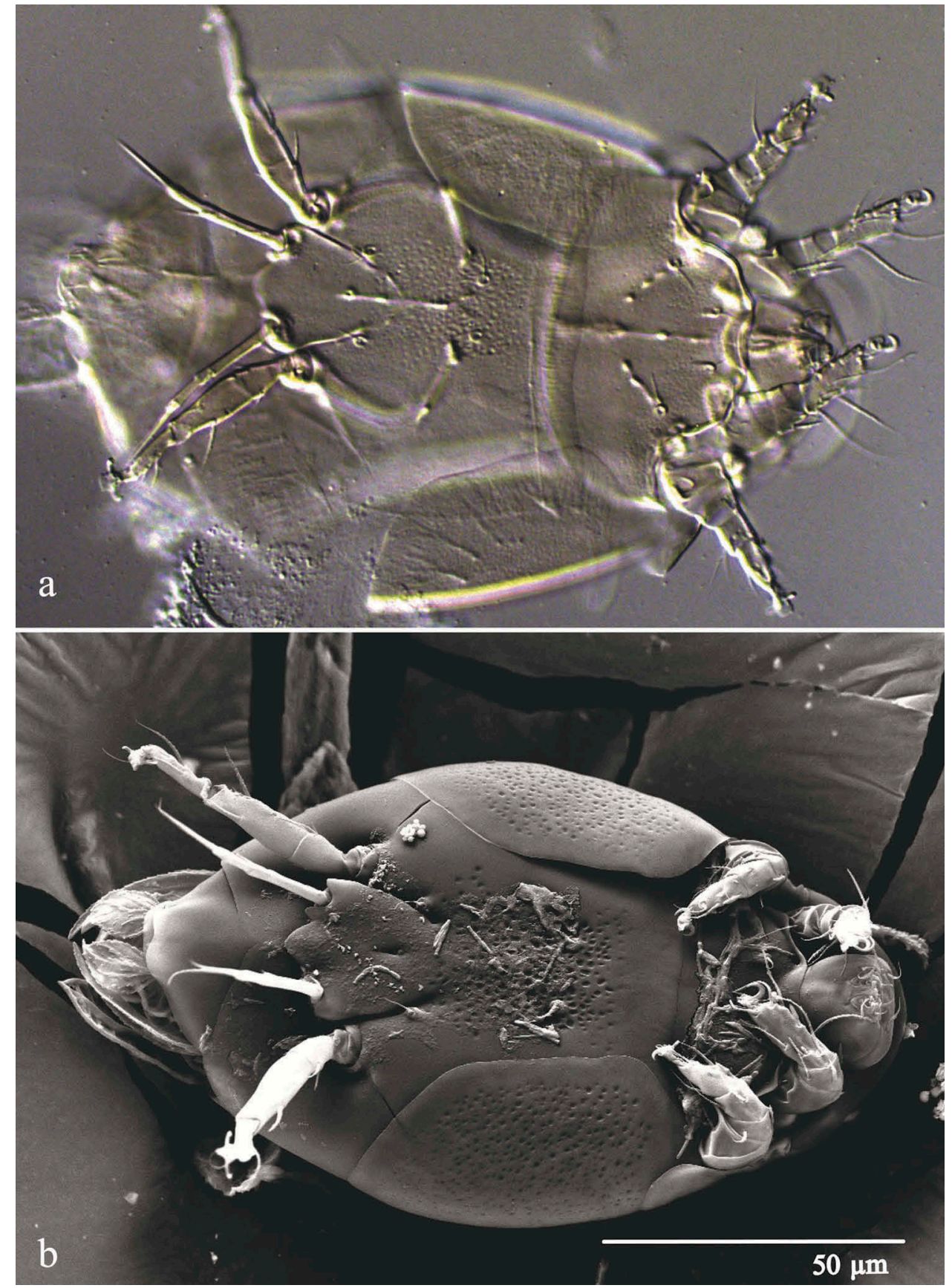

Figure 4. Excelsotarsonemus cabrucae sp. $\mathrm{n}$. (female). Ventral micrographs: (a) differential interference contrast and (b) scanning electron microscopy.

whereas that of E. tupi and E. kaliszewskii are oblong and elongate.

Adult female $(N=7)$. Gnathosoma (Figures 3 and 4). completely covered by the prodorsum and subtriangular in ventral view, length 24, 25 (23-26), maximum width 23, 23 (20-25). Setae dgs 8, 8 (7-11) and $\operatorname{vgs} 7,7$ (5-7) smooth. Palps moderately long 7, 7 (7-8), with 2 small subterminal setae and terminal projections. Pharynx fusiform 15, $14(12-15)$ long and 6, 5 (5-6) wide at maximum width.

Idiosoma - dorsum (Figures 1, 2, and 6). length of all dorsal plates 165, 168 (165-170), width at level of $c 1$ 108, 105 (100110). Stigma inserted proximally at the lateral notch of the prodorsal shield, near to base of setae $v 1$. Lengths of the setae: v1 47, 45 (40-47), sc1 14, 15 (14-16), sc2 42, 43 (4045), c1 70, 71 (65-75), c2 18, 19 (18-24), d 35, 38 (31-43), e 35, 33 (30-37), $f$ 35, 35 (32-39), and $h$ 15, 16 (14-18). Maximum width of expanded setae: $s c 2$ 5, 5 (4-5), c1 9, 9 (8-9), $d$ 20, 19 (17-22), h 3, 4 (3-4), and $f$ 18, 22 (18-25). All dorsal setae serrated. Bothridial seta $s c 1$ capitate. Setae $v 1$, $c 2$, and $e$ setiform and slightly widened; $c 1$ and sc2 lanceolate; $d, f$, and $h$ ovate. Distances between dorsal setae: $v 1-v 1$ 37, 36 (34-39), sc2-sc2 43, 45 (43-47), v1-sc2 18, 18 (17-19), c1-c1 42, 41 (40-42), c2-c2 67, 66 (63-68), c1-c2 15, 14 (13$15), d-d$ 19, 21 (19-22), f-f 15, 15 (14-15), e-f 18, 19 (18-20), and $h-h 10,11(10-11)$. Seta sc2 located laterally to sc1. Dorsal shield with tergite $D$ longer than tergite $C$ covered with tiny dimples, each around $0.3(0.2-0.5)$ in diameter.

Idiosoma - venter (Figures 3, 4, 6, and 7). setae 1a 5, 5 (4-5), inserted on tubercles posteriad of apodemes $1 ; 2 a \mathbf{8}, 8$ (7-10), on anterior margins of apodemes 2; alveolar remnants of setae $1 b$ and $2 b$ present; $3 a$ 8, 8 (7-9) near anteromedial margins of apodemes 3; $3 b$ 9, 8 (7-9) on posterior margins of apodemes 4 . Apodemes 1 conspicuous, fused to anterior end of prosternal apodeme. Apodemes 2 short and not fused to prosternal apodeme. Prosternal apodeme not clearly joined with sejugal apodeme, conspicuous from apodemes 1 to level of apodemes 2, ending in a diffuse area that reaches sejugal apodeme. Sejugal 
a

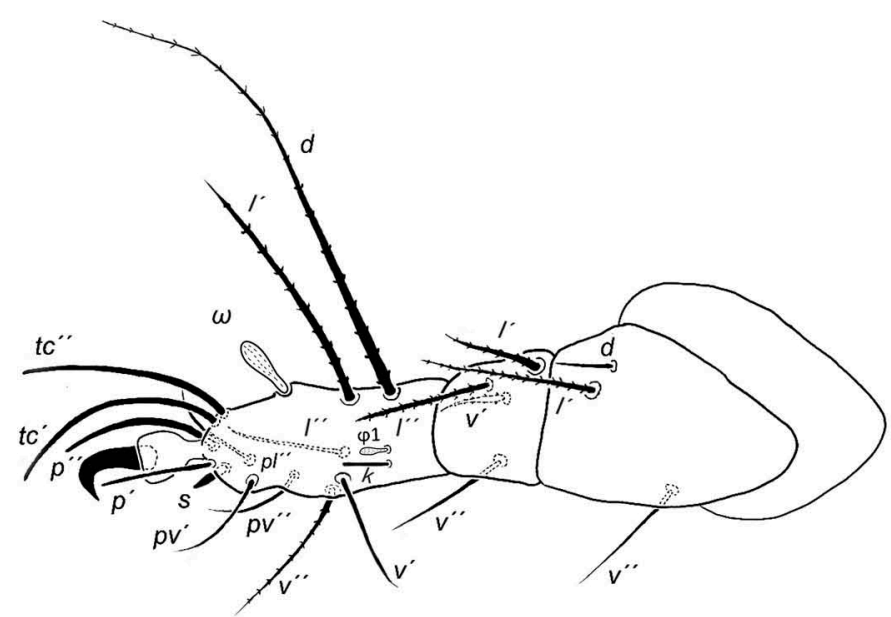

b
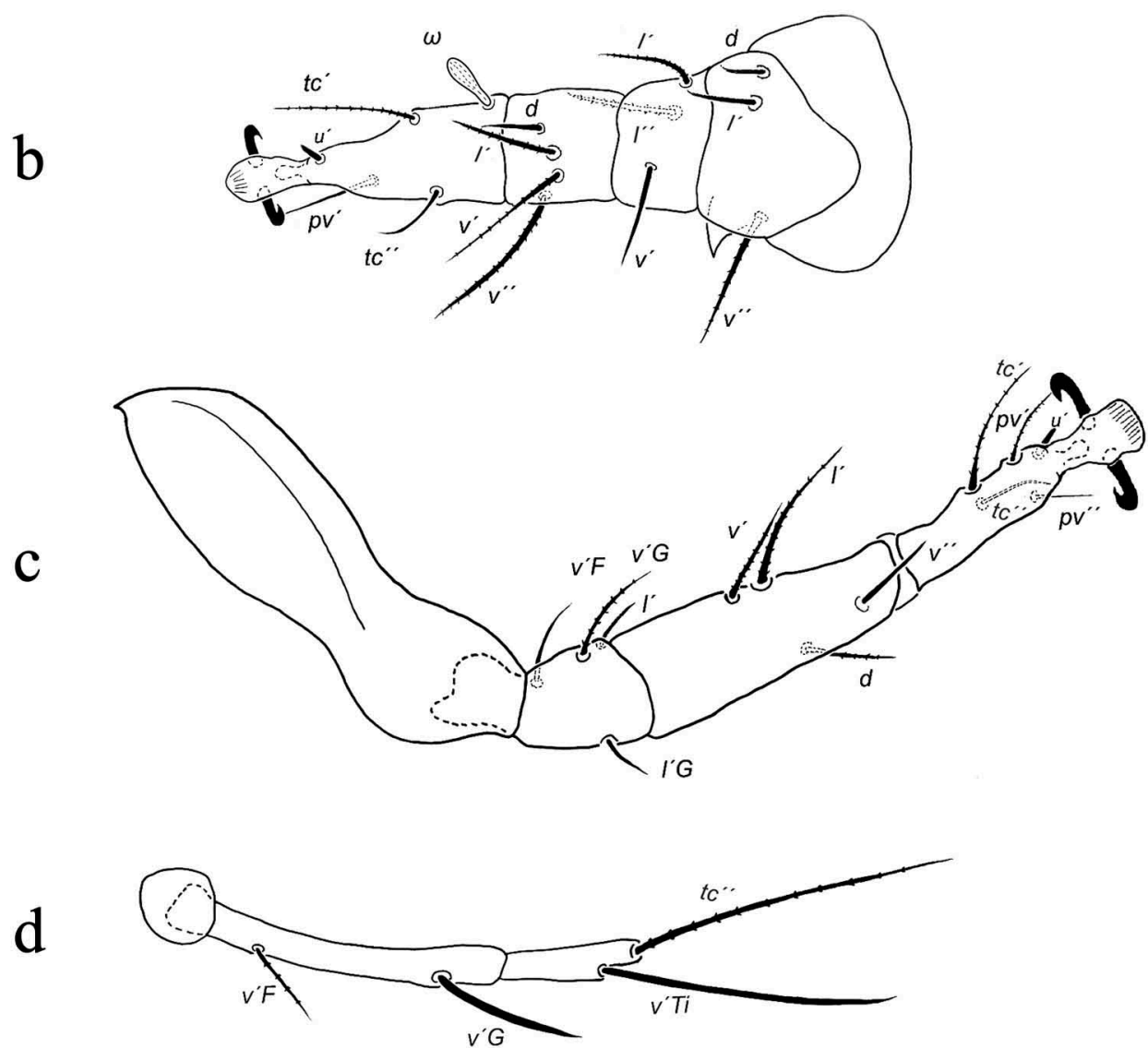

\section{$25 \mu \mathrm{m}$}

Figure 5. Excelsotarsonemus cabrucae sp. n. (female): (a) leg I, (b) leg II, (c) leg III, and (d) leg IV

apodeme uninterrupted. Apodemes 3 with a constriction near trochanter III; apodemes 4 extending diagonally from middle of poststernal apodeme to base of seta $3 b$. Fissures on coxisternal plate IV overlapping apodemes 4, reaching the anterior level of femorogena III and IV. Coxisternal plates covered with tiny dimples, each around $0.3(0.2-0.5)$. Tegula wide 13, $13(13-15)$ and short 7, 7 (7-8), with posterior margin slightly convex. Seta ps 4 smooth.

Legs (Figures 5 and 6). lengths: leg I 45, 44 (42-47), leg II 41, 43 (40-45), leg III 75, 72 (70-75), leg IV 32, 31 (30-33). Number of setae (solenidia in parentheses) on femur, genu, tibia, and tarsus, respectively: leg I: 3-4-6(1)+8(1), leg II: 3-3-4-4(1), leg III: 1+3-4-5, leg IV: 0-2-2. Claws medium-sized, hook-like, empodium in form of subcircular pad; pretarsal stalk expanded at bases of claws. Empodia of legs I, II, and III about the same size or slightly smaller compared to respective basal stalks. Tarsal solenidion $\omega$ of tibiotarsus I 5, stout, wider medially. Sensory cluster of tibia I incomplete, solenidion $\varphi 12$, slender, capitate; famulus $k$ 4, 4 (3-4); both inserted approximately at the same level (Figure 6(a)). Seta $d$ of tibia I 32, 32 (32-34), serrate. Solenidion $\omega$ of tarsus II proximally inserted 5, 5 (4-5) long, stout, wider medially. Seta $d$ of tibia II 5, 6 (5-6), smooth. Femorogenu IV 23, 23 (22-24); tibiotarsus IV 8, 8 (7-9). Length of leg IV setae: v' F 5, 5 (5-7), v' G 9, 9 (8-10), $v^{\prime} \mathrm{Ti}$ 16, 16 (14-18), and $t c^{\prime \prime} 20,19$ (17-20); setae $v^{\prime}$ Ti and $t c^{\prime \prime}$ smooth; $v$ 'Ti falcate. 


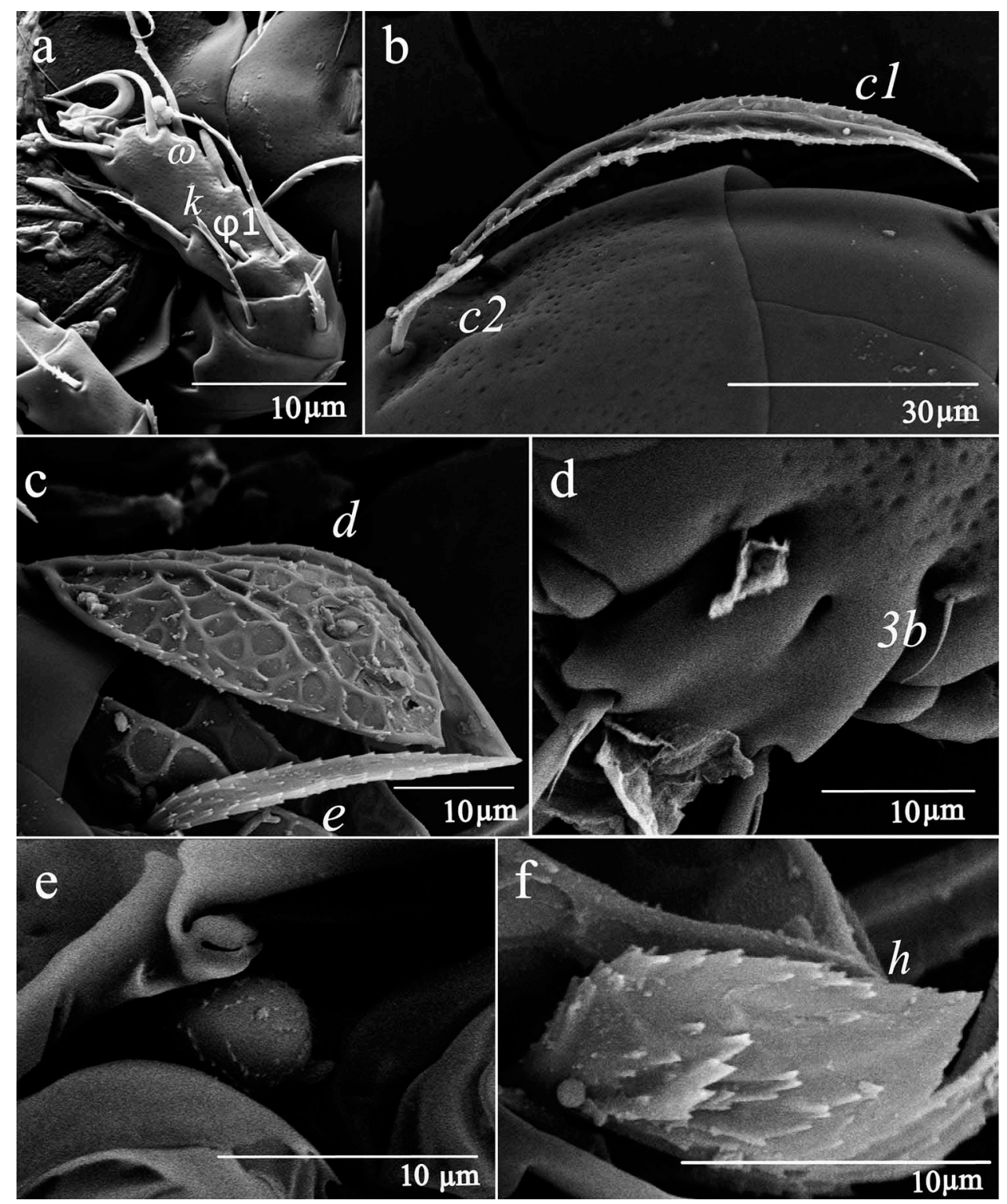

Figure 6. Excelsotarsonemus cabrucae sp. n. (female): (a) sensorial cluster of tibia I, (b) lateral view of the setae $c 1$ and $c 2$, (c) lateral view of the setae $d$ and $e$, (d) details of the tegula, (e) bothridial seta and stigma, and (f) details of the setae $h$.

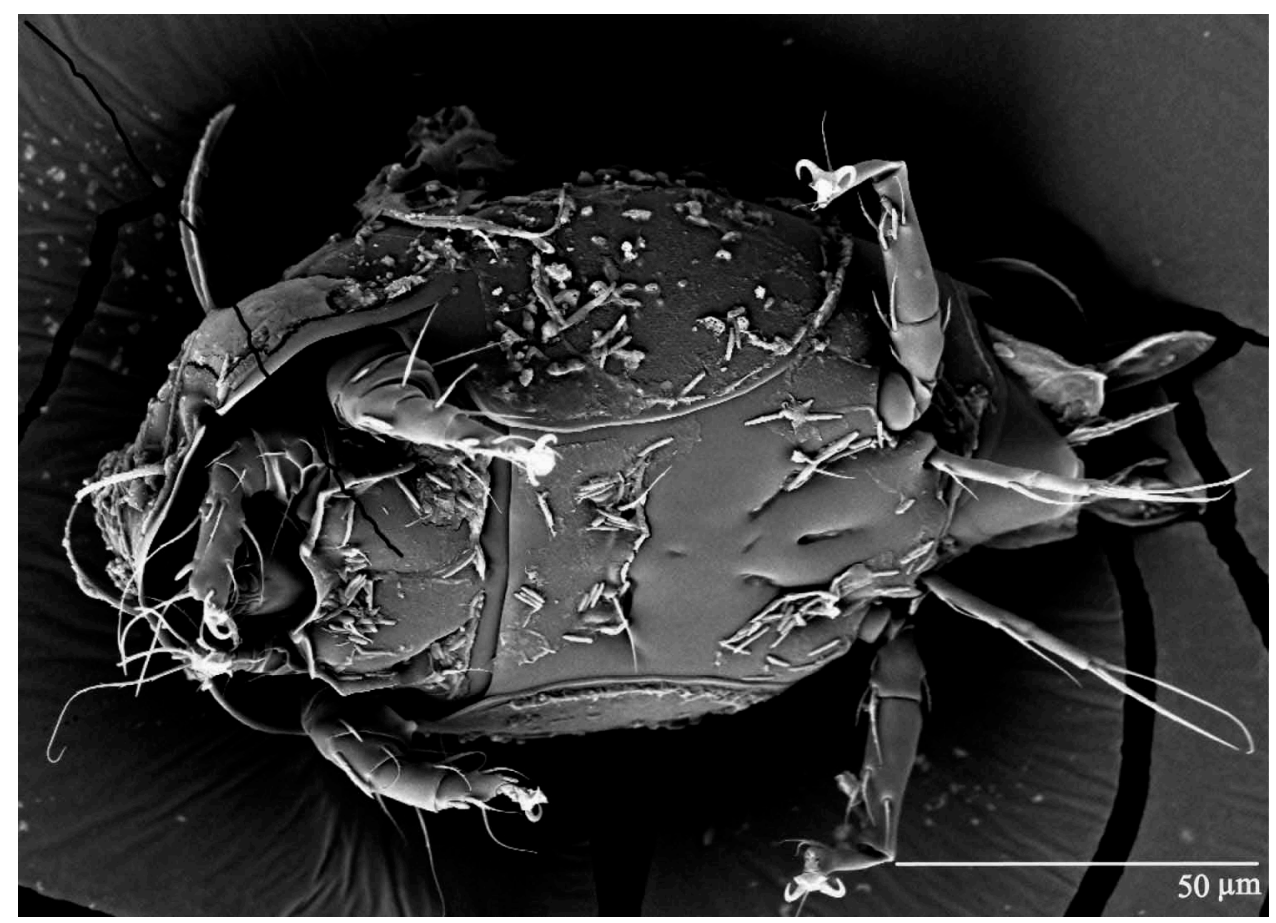

Figure 7. Presence of fungi and bacteria on part of lateral and ventral surface of the Excelsotarsonemus cabrucae sp. $\mathrm{n}$. 


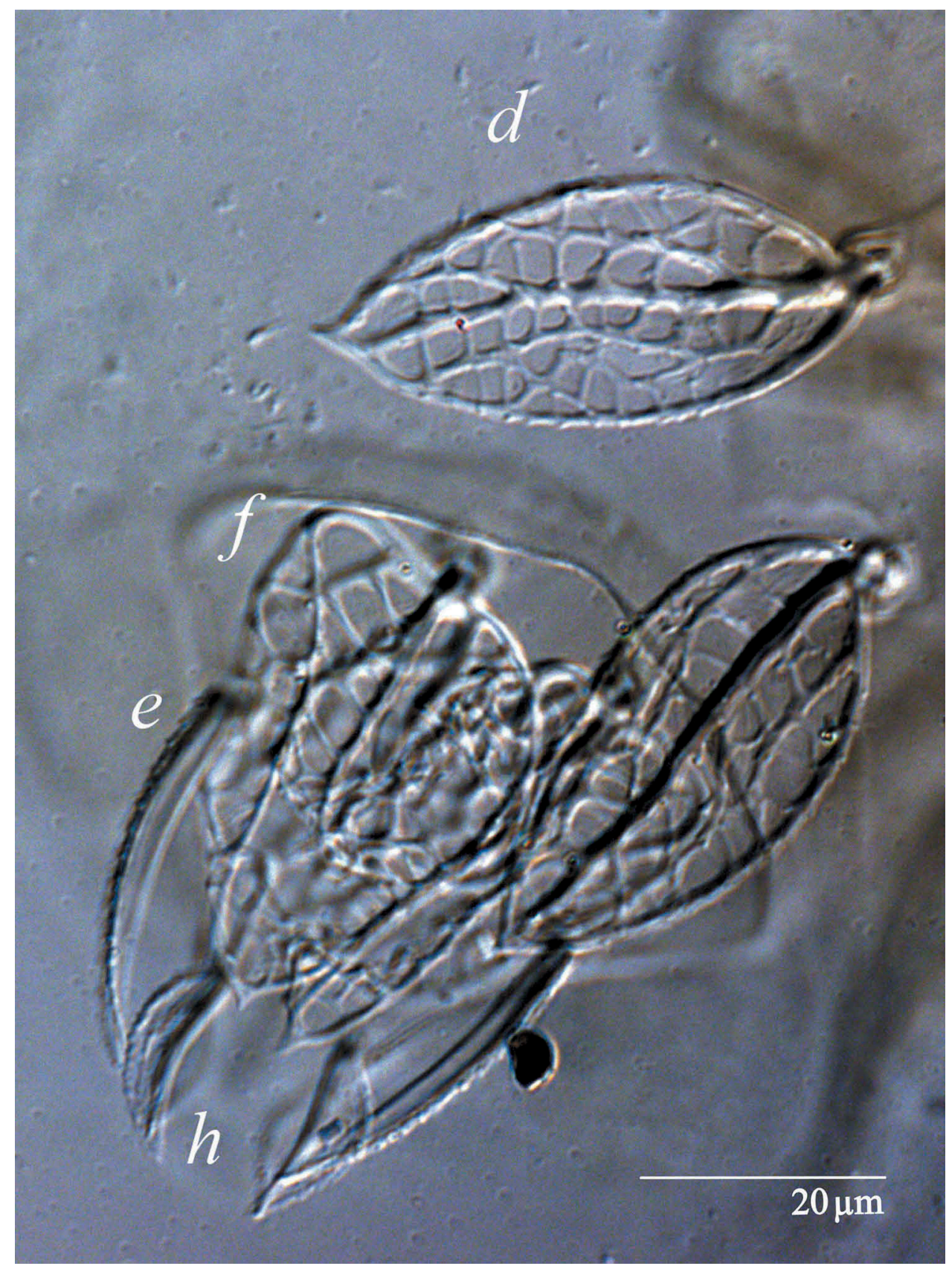

Figure 8. Excelsotarsonemus cabrucae sp. n. Differential interference contrast micrograph of setae $d, f, e$, and $h$.

\section{Adult male and larva. Unknown.}

\section{Type material}

All female specimens were collected by André Silva Guimarães Sousa. Holotype and two paratypes on Artocarpus heterophyllus Lam and four paratypes on Theobroma cacao L., 14 47'47区 S and 3910囚15区 W, Ilhéus, Bahia, Brazil, 14-VIII-2016, 18-I-2016, 16-II2016, 15-III-2016 E 07-XII-2016). Holotype and one paratype deposited in the Acari Collection of the Departamento de Zoologia e Botânica (DZSJRP), São José do Rio Preto, State of São Paulo, Brazil [AC-DZSJRP], two paratypes deposited at United States National Museum of Natural History, Smithsonian Institution, hosted in Beltsville, Maryland, USA, two paratypes deposited at Acari Collection of the Entomology Laboratory, in Universidade Estadual de Santa Cruz, Ilhéus, State of Bahia, Brazil [AC-UESC], and one paratype deposited at Escola Superior de Agricultura "Luiz de Queiroz," ESALQ, Universidade de São Paulo, Piracicaba, São Paulo, Brazil [AC-ESALQ].

\section{Etymology}

The species name cabrucae comes from the cabruca agrosystem which contains cacao trees in association with the jackfruit trees and other plants in the tropical forest. This agricultural system can be found in Brazil, mainly in the coastal region of the state of Bahia, where this mite species was found.

\section{Remarks}

Excelsotarsonemus cabrucae has a fissure which appears to extend from between bases of legs III and IV to level of seta $3 b$ where it overlaps slightly with posterolateral end of apodeme 4 and poststernal apodeme bifurcated anteriorly; similar structures are present in Daidalotarsonemus puntarenensis Rezende, Ochoa \& Lofego and Daidalotarsonemus serratus Rezende, Ochoa \& Lofego (Rezende et al. 2015c). Besides the genera Excelsotarsonemus and Daidalotarsonemus, such fissures overlapping apodemes 4 have also been observed in the genus Metatarsonemus (Attiah 1970; Lindquist 1985; 
a<smiles>[Mg]</smiles>

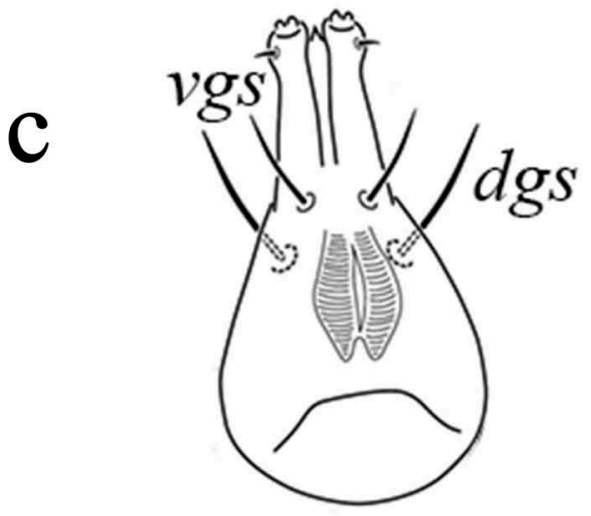

b

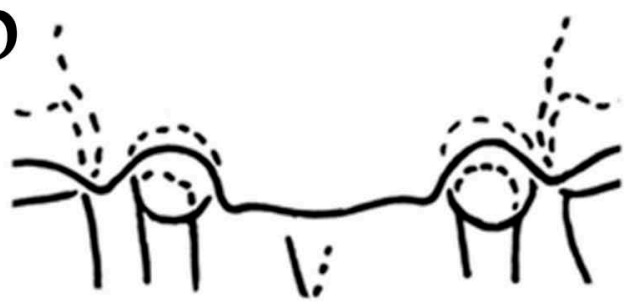

1

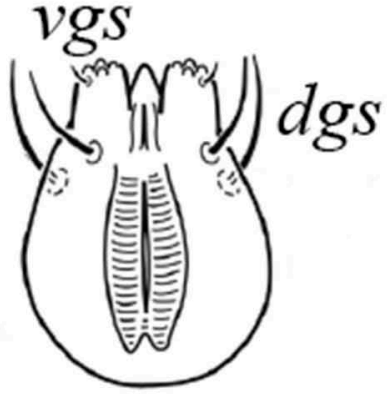

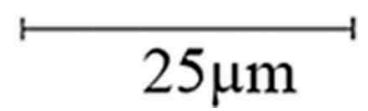

Figure 9. $(\mathrm{a}, \mathrm{b})$ : Tegula of $D$. annonae and $D$. maryae, respectively; $(\mathrm{c}, \mathrm{d})$ : Gnathosoma of $D$. esalqi and $D$. oliveirai, respectively.

Lofego et al. 2005). The dorsal shield has tergite D longer than tergite $C$, smooth, covered with tiny dimples, each around $0.3(0.2-0.5)$ in diameter; setae $c 1, c 2, d, f$, and $e$ are distinctly elongate. Setae $h$ is short $\left( \pm 3^{\circ} \mu \mathrm{m}\right)$ and ovate shape, setae sc2 and $c 1$ are lanceolate, and setae $f$ has internal cavities and veins (Figure 8). The fissures on coxisternal plate IV overlapping apodemes 4 extend to the anterior level of femorogena III and IV. Females of the genus Excelsotarsonemus have most of their dorsal setae very wide and with intricate folding patterns (Rezende et al. 2015a).

Key to the species of Daidalotarsonemus from Brazil (based only on females):

1. Setae $c 1$ inserted near posterior border of tergite $C$; tegula rounded apically

- Setae $C 1$ inserted in the middle of the tergite $C$ or near anterior margin of this plate; tegula truncated apically........ 4

2. Posterior dorsal setae $d$ and $f$ elliptical with two serrate veins; setae sc2 falcate.

- Posterior dorsal setae $d$ and $f$ ovate; setae sc2 setiform D. annonae Sousa, Lofego \& Gondim Jr. (Figures 9(a) and 10(a))

3. Setae $e$ lanceolate; setae $c 1$ long $( \pm 30 \mu \mathrm{m})$; setae $d$ narrower $( \pm 7 \mu \mathrm{m})$ and length $( \pm 31 \mu \mathrm{m})$.

.. D. lini Ochoa, Rezende \& Lofego (Figures 9(b) and 11(d))

- Setae e elliptical; setae $c 1$ long $( \pm 18 \mu \mathrm{m})$; setae $d$ wider $( \pm 10 \mu \mathrm{m})$ and length $\left( \pm 25^{\circ} \mu \mathrm{m}\right) ; \ldots . .$. D. maryae Ochoa, Rezende \& Lofego (Figures 9(c), 10(b), and 11(e))

4. Tergite $\mathrm{C}$ without rows of reticula. 5

- Tergite $C$ with at least one row of reticula ................................... 6

5. Setae $c 1$ elongate $( \pm 24 \mu \mathrm{m})$; setae $e$ filiform

D. folisetae Lofego \& Ochoa (Figures $9(\mathrm{~g})$ and 11(a))

- Setae $c 1$ short $( \pm 11 \mu \mathrm{m})$; setae e cordate. D. oliveirai Rezende, Lofego \& Ochoa (Figures 9(d), 10(d), and 11(b))
6. Setae $e$ lanceolate $( \pm 3 \mu \mathrm{m})$; palps long $( \pm 17 \mu \mathrm{m})$.

D. esalqi Rezende, Lofego \& Ochoa (Figures 9(e) and 10(c))

- Setae e broad $( \pm 15 \mu \mathrm{m})$; palps short $( \pm 9 \mu \mathrm{m})$.

7. Setae $c 1, c 2$ setiform.

D. savanicus Rezende, Lofego \& Ochoa (Figures $9(\mathrm{f})$ and $11(\mathrm{c})$ )

Key to the species of Excelsotarsonemus of the world (based only on females):

1. Setae sc2 setiform . 2

- Setae sc2 elliptical.

2. 2 Setae e symmetrical, orbicular, and smooth; surface of tergite $\mathrm{C}$ smooth; absence of fissure flanking the tegula..........

E. kimhansenae Ochoa \& OConnor

- Setae $e$ asymmetrical; surface of tergite $C$ with a U-shaped pattern; presence of fissure flanking the tegula

E. caravelis Rezende, Lofego \& Ochoa

3. Setae $d$ symmetrical and elliptical in shape 4

- Setae $d$ asymmetrical, bilobate, and heavily sculptured............ E. mariposa Ochoa \& OConnor

4. Setae $c 2$ lanceolate; setae $e$ slightly falcate and very elongate $( \pm 66 \mu \mathrm{m})$

E. kaliszewskii Ochoa \& Naskrecki

- Setae c2 setiform; setae $e$ setiform and not very elongate $\left( \pm 30^{\circ} \mu \mathrm{m}\right)$

5. 5 Setae sc2 serrate oblong; without a fissure flanking the tegula.

E. tupi Rezende, Lofego \& Ochoa

- Setae Rezende, Lofego sc2 lanceolate; with a fissure flanking the tegula

Excelsotarsonemus cabrucae sp. $\mathbf{n}$.

\section{Discussion}

In recent years, five different genera of tarsonemid have been found in the tropical forests of Brazil (Excelsotarsonemus, Biscutulumnemus, Kaliszewskia, Ochoanemus, and Daidalotarsonemus) (Ochoa et al. 1995; Ochoa and OConnor 
a

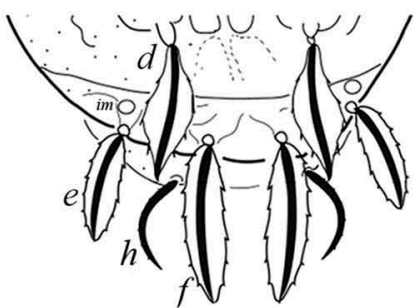

b

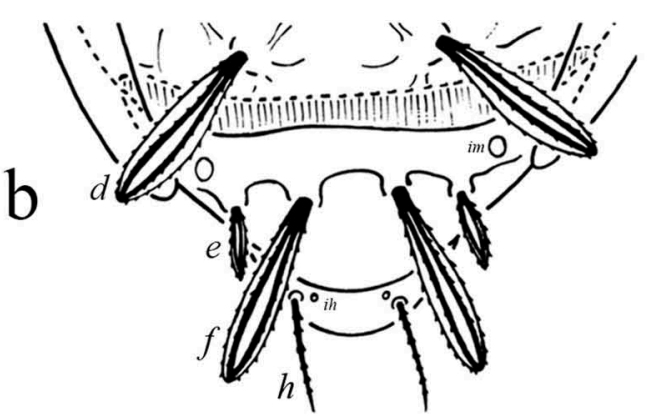

C
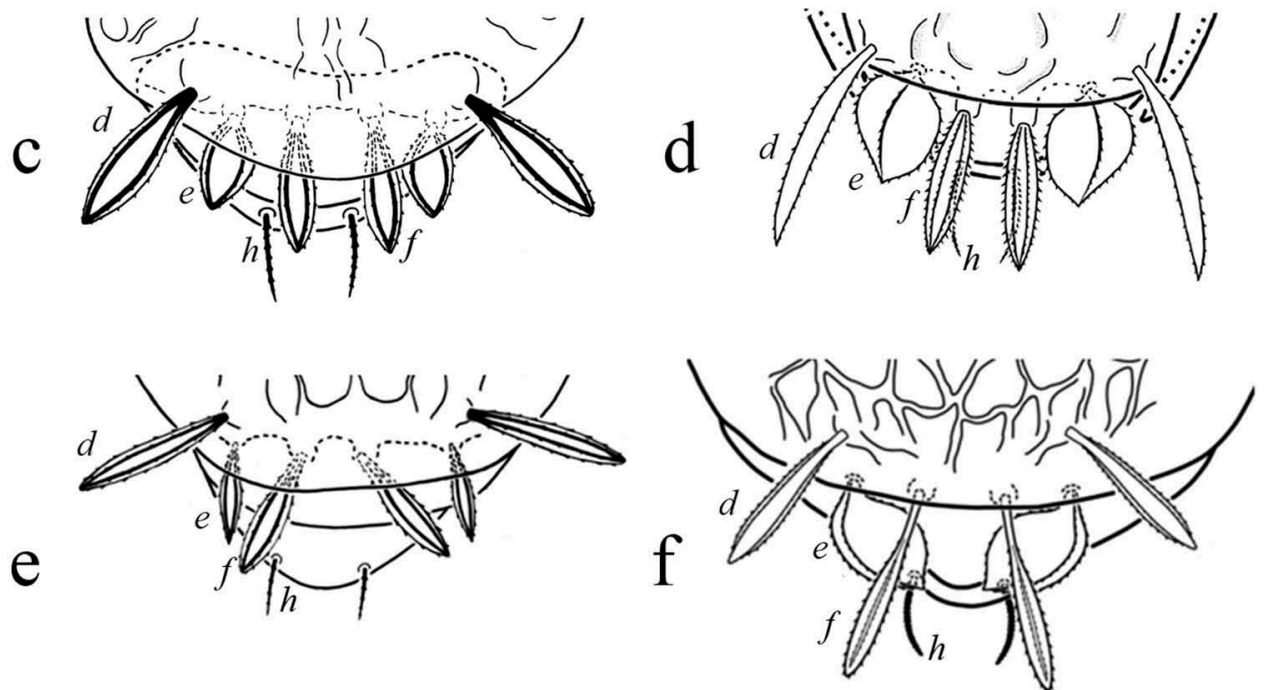
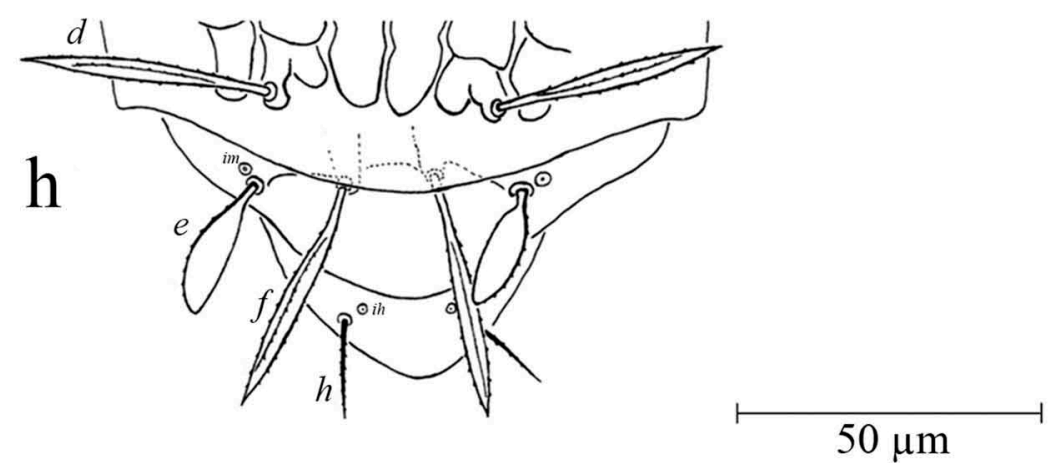

Figure 10. Shape of the posterior setae d, e, f, and h: (a) D. annonae, (b) D. lini, (c) D. maryae, (d) D. oliveirai, (e) D. esalqi, (f) D. savanicus, and (g) D. folisetae.

1998; Lofego and Feres 2006; Lofego et al. 2015, 2016; Rezende et al 2015a, 2015b; 2015c). Daidalotarsonemus and Excelsotarsonemus are among the most diverse tarsonemid genera in this biome, with several species recorded on cocoa trees (Ochoa et al. 1995; Ochoa and OConnor 1998; Rezende et al. 2015a). The species $D$. lini and D. maryae are recorded for the first time in Brazil in this study, as they were first described in Costa Rica (Rezende et al. 2015c). Both species were collected from the tropical forests in Costa Rica and Brazil.

In the rainforest, cocoa trees act as a host-trap for the adult female mites falling from the canopies, indicative of a closer association with the climate and general environment rather than a host plant association. The females found are possibly being trapped while in the stage of the wind dispersion from canopy host plants using their large erect setae on the top of their body like sails (Ochoa and OConnor 1998). In the future, the canopy plants need to be better investigated to find males, larvae, and eggs. Oliveira and Sousa observed some adult females of these genera, in particular Daidalotarsonemus, living on the bark of the trunk and the surface of the branches maybe indicating dietary associations with the saprophytic fungi and lichen.

These genera are commonly collected with fungi and bacteria present on the dorsal tergites and some modified setae ( $e$ and $f$ ). Possibly, they may be feeding on fungi, algae, or lichen in the different canopy ecosystems, and the wind dispersal of the mites with these organisms is in need of research (Ochoa et al. 1995; Ochoa and OConnor 1998; Rezende et al. 2015a). This is important because of the potential association of these mites with fungal and bacterial diseases in this ecosystem (Johns 1999). Therefore, although in this paper we do not intend to document direct mite associations with fungi and bacteria, some species of these genera might be useful indicators of biodiversity in stable environments since many species found in cabruca have been previously found only in undisturbed environments. The high 

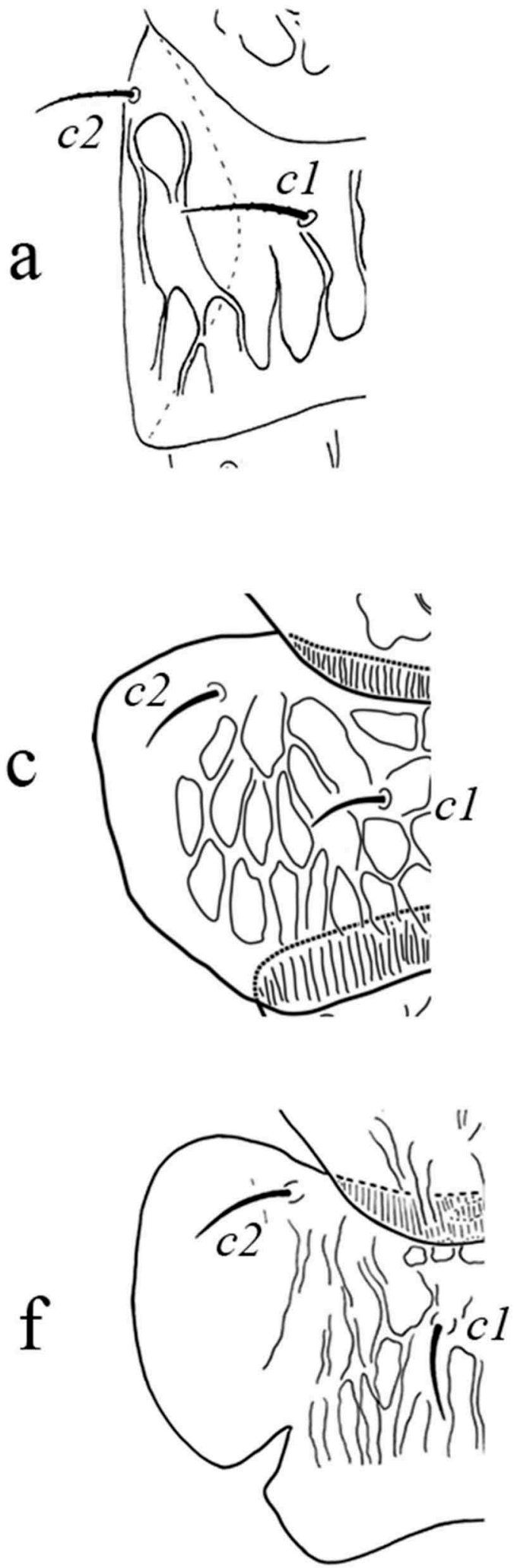
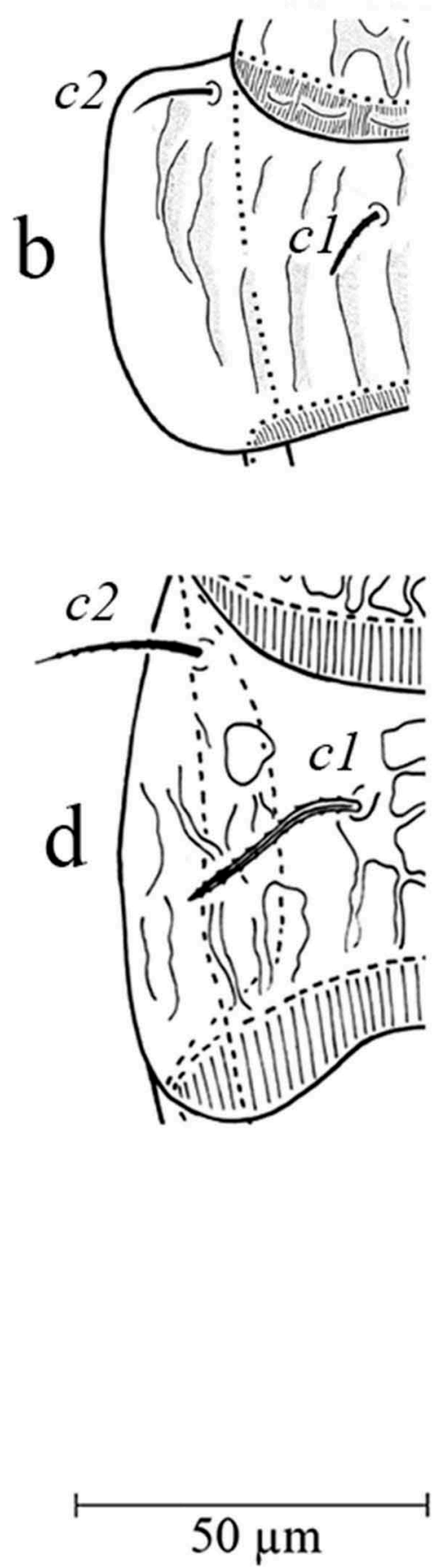

Figure 11. Shape of the dorsal setae $c 1$ and c2: (a) D. folisetae, (b) D. oliveirai, (c) D. savanicus, (d) D. lini, and (e) D. maryae.

number of tarsonemid species observed inhabiting this ecosystem shows the importance of preserving the cabruca system and its unique biodiversity. The great biodiversity present in this ecosystem is not limited to just tarsonemids but includes other animal groups as well (Faria et al. 2006, 2007). Future research in this work area presents a unique opportunity to observe interactions between these diverse mite communities to gain insight into their relations between other mite families that was also found in the same biome (de Carvalho et al. 2017). The cabruca system has been shown to be a balanced production system that contributes to the biodiversity conservation, since it is a low- impact economic activity that retains moisture, soil quality, biotic waste, and stable temperature.

\section{Acknowledgements}

The authors thank "Fundação de Amparo à Pesquisa do Estado da Bahia" (FAPESB) and "Coordenação de Aperfeiçoamento de Pessoal de Nível Superior" (CAPES) for the scholarship to the first author. The authors thank "Fundação de Amparo à Pesquisa do Estado de São Paulo" (FAPESP) for the financial support to the second author 
(Procs. 2015/19867-0 and 2016/16779-5). A.C. Lofego received a research productivity fellowship from CNPq (Proc. no. 304562/20157). The authors specially thank Lucas Ribeiro and Larissa Simões ("Centro de Microscopia Eletronica" (CME), Universidade Estadual de Santa Cruz (UESC)) for their technical support of the SEM; Debra Creel and Andrew Ulsamer (SEL-USDA) for their assistance with references and collection material; Dr Gregory Evans (APHIS USDA) for the revision of the manuscript; and the Smithsonian National Museum of Natural History (NMNH), National Agricultural Library (NAL), Systematic Entomology Laboratory (SEL-USDA) for their support with specimens, references, and equipment. The mention of trade names or commercial products in this publication is solely for the purpose of providing specific information and does not imply recommendation or endorsement by the USDA, UESC and UNESP; USDA is an equal opportunity provider and employer.

\section{Disclosure statement}

No potential conflict of interest was reported by the authors.

\section{Funding}

This work was supported by the Fundação de Amparo à Pesquisa do Estado da Bahia (FAPESB) [BOL0608/2015]; Fundação de Amparo à Pesquisa do Estado de São Paulo (FAPESP) [2015/19867-0,2016/ 16779-5]; CNPq [304562/2015-7]; Coordenação de Aperfeiçoamento de Pessoal de Nível Superior (CAPES) [88881.132452/2016-01].

\section{ORCID}

Antonio Carlos Lofego (D) http://orcid.org/0000-0002-3495-6858

\section{References}

Attiah HH. 1970. New tarsonemid mites associated with citrus in Florida (Acarina: Tarsonemidae). The Florida Entomologist 53:179-201.

Canty JL, Breitbart S, Frischling DA 2008. Weatherbase. [Cited 2017 June 01. Available from http://www.weatherbase.com/.

de Carvalho AN, Oliveira AR, Sá Argolo P, Ferragut F. 2017. Three new species of phytoseiid mites (Acari: Phytoseiidae) from Bahia State. Brazil. Zootaxa 4272:142-150.

Faria D, Paciencia MLB, Dixo M, Lapz RR, Baumgarten J. 2007. Ferns, frogs, lizards, birds and bats in forest fragments and shade cacao plantations in two contrasting landscapes in the Atlantic Forest, Brazil. Biodiservs Conserv 16:2335-2357.

Faria D, Soares-Santos B, Sampaio E. 2006. Bats from the Atlantic rainforest of Southern Bahia, Brazil. Biota Neotropica 6:1-13.

Johns ND. 1999. Conservation in Brazil's chocolate forest: the unlikely persistence of the traditional cocoa agroecosystem. Environmental Management 23:31-47.

Joly CA, Metzger JP, Tabarelli M. 2014. Experiences from the Brazilian Atlantic Forest: ecological findings and conservation initiatives. New Phytologist 1:1-14.

Khaustov AA, Abramov VV. 2017. A new genus and species of Tarsonemidae (Acari: Heterostigmata) associated with Aradus betulae (Heteroptera: Aradidae) from European Russia. Acarologia 57:1079-1087.

Lin J, Zhang ZQ. 2002. Tarsonemidae of the world: key to genera, geographical distribution, systematic catalogue \& annotated bibliography. London: Systematic and Applied Acarology Society. p. 440.
Lindquist EE. 1985. Description of the adult female of the typespecies of Metatarsonemus Attiah, with notes on the synonymy of this genus under Tarsonemus Can. and Fanz. (Acari: Tarsonemidae). Canadian Entomologist 17:1279-1285.

Lindquist EE. 1986. The world genera of Tarsonemidae (Acari: Heterostigmata): a morphological, phylogenetic and systematic revision, with classification of family-group taxa in the Heterostigmata. Ottawa: The Entomological Society of Canada 136:1-517.

Lofego AC, Demite PR, de Moraes GJ. 2015. A new genus and species of Tarsonemidae (Acari: Heterostigmata) from the Atlantic Forest, Brazil. Zootaxa 3986:561-568.

Lofego AC, Feres RJF. 2006. A new genus and species of tarsonemid mite (Acari: Tarsonemidae) from Brazil. Zootaxa 1299:45-55.

Lofego AC, Ochoa R, Gj DM. 2005. Some tarsonemid mites (Acari: Tarsonemidae) from the Brazilian "Cerrado" vegetation, with descriptions of three new species. Zootaxa 823:1-27.

Lofego AC, Pitton T, Rezende JM. 2016. A new genus and new species of Tarsonemidae (Acari: Heterostigmata) from the Brazilian rainforests. Systematic \& Applied Acarology 21:307-319.

Magowski WL, Di Palma A, Khaustov AA. 1998. Ununguitarsonemus rarus (Acari Tarsonemidae): a new species of mite associated with bark beetle from Crimea, Ukraine. Entomologica (Bari) 32:139-151.

Magowski WL, Lindquist EE, Moser JC. 2005. Giselia arizonica, a new genus and species of mite (Acari: Tarsonemidae) associated with bark beetles of the genus Pseudopityophthorus (Coleoptera: Scolytidae) in North America. The Canadian Entomologist 137:648-656.

Mittermeier RA, Gil PR, Hoffmann M, Pilgrim J, Brooks J, Miitermeier CG, Lamourux J, Fonseca GAB. 2004. Hotspots revisited: earth's biologically richest and most endangered terrestrial ecoregions. Washington (DC USA): Cermex. p. 200.

Ochoa R, Naskrecki P, Colwell RK. 1995. Excelsotarsonemus kaliszewskii, a new genus and new species from Costa Rica (Acari: Tarsonemidae). International Journal of Acarology 21:67-74.

Ochoa R, OConnor BM. 1998. Two new species of the genus Excelsotarsonemus (Acari: Tarsonemidae). International Journal of Acarology 24:179-187.

Rezende MJ, Lofego AC, Ochoa R. 2015a. New species of Daidalotarsonemus and Excelsotarsonemus (Acari, Tarsonemidae) from the Brazilian rainforest. ZooKeys. 475:1-36.

Rezende MJ, Lofego AC, Ochoa R. 2015b. Two new species of Daidalotarsonemus (Acari: Prostigmata: Tarsonemidae) from Brazil. Acarologia 55:435-448.

Rezende MJ, Ochoa R, Lofego AC. 2015c. Ten new species of Daidalotarsonemus (Prostigmata: Tarsonemidae) from Costa Rica. International Journal of Acarology 41:449-493.

Sambuichi RHR, Vidal DB, Piasentin FB, Jardim JG, Viana TG, Menezes AA, Baligar VC. 2012. Cabruca agroforests in southern Bahia, Brazil: tree component, management practices and tree species conservation. Biodiversity Conservation 21:1055-1077.

Schroth G, Faria D, Araujo M, Bede L, Van Bael SA, Cassano CR, Delabie JHC. 2011. Conservation in tropical landscape mosaics: the case of the cacao landscape of southern Bahia, Brazil. Biodiversity and Conservation 20:1635-1654.

Sousa JM, Lofego AC, Gondim JRMGC. 2014. Two new species of tarsonemid mites (Acari: Tarsonemidae) from northeastern Brazil. Zootaxa. 3889:429-441.

Suski Z. 1967. Badania nad roztoczami z rodziny Tarsonemidae (Acarina, Heterostigmata) występującymi na jabłoniach w Polsce. Skierniewice: Institute of Pomology and Floriculture. p. 268. 